\title{
ПАЛЕСТИНСКА КРАТКА ПРИЧА У САВРЕМЕНОЈ АРАПСКОЈ КЫИЖЕВНОСТИ
}

\begin{abstract}
У овом раду се бавимо палестинском кратком причом и њеним местом у савременој арапској књижевности. У историји арапске књижевности палестинска књижевност заузима посебно место јер је уско везана и за политичке догађаје и за саму књижевност. Модерна палестинска кратка прича, као и арапска уопште, настала је под утицајем Запада и штампе. Она се посебно бави темама националноослободилачке борбе против империјализма и колонијализма. При томе се не ради, бар код зрелијих стваралаца, о паролошкој литератури, већ о литератури која је настојала да открије и укаже на значајне моменте у арапској и палестинској историји која ће допринети садашњем арапском друштвеном тренутку. Међу темама, на првом месту је, свакако, болни и трауматски проблем палестинског народа који је од 1948. године избачен из својих домова и са своје земље. У првом делу рада се бавимо настанком и развојем модерне кратке приче у арапском свету, уопште, и на палестинском тлу, посебно. Док у другом делу представљамо најистакнутије палестинске ауторе модерне кратке приче попут Халила Бајдаса, Наџве Фарах, Самире Азам, Гасана Канафанија и њихова дела.
\end{abstract}

Кључне речи: кратка прича, палестинска књижевност, диглосија, арапска књижевност, пионири

\section{1. Увод}

Арапи су приповедачка нација плодне маште и непресушне инспирације. Приповетка има своју традицију у народној књижевности јер су још у преисламском периоду постојале многе приче које говоре о прошлости Арапа, о њиховим јунацима и међуплеменским борбама. У абасидском периоду Арапи су упознали, преузли и превели многе

Филолошки Факултет, Студентски трг 3, 11000 Београд, електронска пошта: mai7987@gmail.com. 
приповести разних оријенталних народа, првенствено из Персије и Индије, од којих је најпознатији зборник прича Хиљаgу и јеgна ноћ.

На једној таквој богатој традицији, након буђења националне свести и раздобља просвећености у XIX и почетком XX века почиње да се уобличава нова књижевност. Продор Европљана у том периоду донео је на арапске просторе колонијализам, империјализам и окупацију, али и интелектуални и културни препород. Европски утицај се осетио у свим порама друштвеног и интелектуалног живота, а велику улогу у арапском препороду је одиграла штампа.

Појава и нагло ширење штампе представљају један од најзначајнијих фактора у развоју културе, формирању политичког живота и нових схватања. Са развојем штампе, новински чланак, као и политичка, социјална и научна проза заузели су посебно место. Као резултат директног учешћа књижевника у политичким борбама, јавља се и политичка сатира, која постаје један од најомињенијих и најбитнијих видова савремене арапске књижевности.

Модерна кратка прича је, као и роман или позориште, настала под утицајем Запада; то је приповедачки жанр европског порекла. Појаву кратке приче у савременој арапској књижевности дугујемо, поред западног утицаја, и арапском књижевном новинарству које је одиграло темељну улогу у њеној афирмацији и ширењу. „Приповетка је управо захваљујући својој сажетости током деценија постала делотворно књижевно оруђе у којем су се Арапи све више проналазили“ (d'Aflito, 2012: 215).

Приповетке и кратке приче све чешће се појављују на страницама арапских часописа, а писци временом стичу већу слободу и изграђују свој стил и поетику, који је до тада, у великој мери, био оптерећен традицијом. Све чешће се у многим арапским часописима, не нужно књижевним, објављују приповетке у наставцима, кратке и веома кратке приче које су у односу на дуже прозне форме, понудиле ауторима једноставнији и непосреднији изражајнији оквир.

\section{2. Арапски језик и кратка прича}

Морална, духовна и политичка обнова арапског света почиње почетком XIX века. Језичко питање покренуо је, крајем деветнаестог 
века, Ибрахим Јазиџи (Ibrāhīm al-Yazīğīi) ${ }^{1}$, кога су називали учитељем језика (ap. Mu'allimal-luga), због личног доприноса поновном процвату арапског језика (d'Aflito, 2012: 38). Ваља поменути да „У арапском свету и даље постоји феномен диглосије ${ }^{2}$, односно писаног језика који се разликује од говорног, а који се опет дели на стианgарни језик, употребљиван у службеним приликама и у медијима, и на језик локалног наречја, који се погрешно назива „дијалекталним“, различит од места до места, од области до области, од града до града““ (d’Aflito, 2012: 216).

Ново доба, нарочито после Другог светског рата, када бројне арапске земље стичу, ако не, независност, онда, макар делимично политички и државни идентитет, означава поступно ослобађање арапског ума од последица колонијализације. Алжирска револуција (1954-1962), је томе дала посебан полет. У Магребу, најчешће, интелектуалци објављују на француском језику, иако је арабизација у Мароку, Алжиру и Тунису, постигла изврсне резултате. Крај Другог светског рата је потврдио све дубљу политичку и географску подељеност у арапском свету. Таква ситуација се, несумњиво, одразила, и на језичко питање. Књижевни језик је јединствен за све Арапе, али је с независношћу арапских земаља, постала осетнија и подела међу Арапима, постало израженије питање дијалеката, нарочито у драмској књижевности. Двојба око употребе књижевног језика, разумљивог само за образоване, или народног којим се сви служе, постаје предмет расправе још крајем деветнаестог века. Неки заговарају чак стварање „трећег језика“ који би био компромис између богатог књижевног и народног језика. Поред тога, постоји тенденција аутора да пишу на дијалекту земље или регије из које долазе. Писци попут Махмуда Тејмура, Халила Бајдаса, Самире Азам и Махмуда Шукајра као и многи други аутори су, најчешће, користили дијалекат у својим дијалозима, такође су користили имена из народних фолклорних прича како би објаснили ликове о којима су писали.

1 У раду је коришћен систем ЗДМГ транскрипције за изворне називе дела и имена аутора на арапском језику.

2 Диглосија подразумева употребу два или више варијетета једног језика. Велики број светских језика поред арапског, поседује овај социолингвистички феномен. О проблему језика у арапском свету, Уп. A.F. Beeston, The Arabic Language today, Hutchinson University Library, London, 1970. УП. Танасковић, Митровић, Грамайика арайскоі језика, Завод за уџбенике, Београд, 2011. стр. 13. 
Франческо Габријели, у делу Арайска књижевносй, каже да се дијалекат користи у дијалошким досеткама у делу приповедачке прозе, у комедији, у хумористичким листовима и у филмском говору, а велики је утицај новинарства и публицистике. Наиме, штапма је осетно утицала на народни језик дајући право грађанства читавом речнику (Gabrijeli, 1985: 253), а од народног језика прихватио синтаксичка поједностављења и лексичке елементе.

Са променама на језичком плану стигле су, почетком XX века, промене и у уметности. У књижевности се рађају нови жанрови и стилови, попут, приповетке, романа, слободног стиха и драме. Такође се афирмишу сликарство и вајарство. Ваља истаћи да, приповетка није сасвим нов жанр у арапском књижевном стваралаштву ако узмемо у обзир басне из дела Калила и Димна (ар. Kìtāb Kalīla wa Dimna), Ибн ал Мукафе (Ibn al-Muqafa‘, VIII век), приче из „1001 ноћ“, за које се сматра да потичу из IX века. У народној књижевности приповетка има своју традицију, али модерна кратка прича, као и роман или позориште, настали су под утицајем Запада. Значајну улогу у развоју и афирмацији кратке приче је, несумњиво, имала штампа. Термини који се, у савременој арапској књижевности, користе за означавање кратке приче јесу qișșa qașīra, riwāya qașīra, uqșūṣa или hịkāya (d'Aflito, 2012: 215). Поред ових термина, у палестинској књижевној традицији

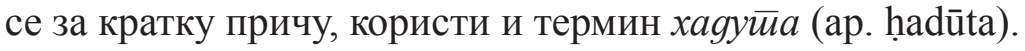

\section{1. Пионири савремене кратке приче код Арапа}

Двадесетих година XX века издвојили су се египатски писци попут браће Мухамеда (Muhamad Tауmūr), и Махмуда Тејмура (Maḥmūd Taymūr), који су били први који су се опробали у краткој причи. Они се сматрају претходницима модерне арапске приче, које ће, потом, наследити Теуфик ел Хаким (Tawfĩq al-Hakim), Махмуд Тахир Лашин (Maḥmūd Tahir Lašīn) и Јахја Хаки (Yaḥyā Ḥakī). Браћа Иса ('İsā) и Шихата Убајд (Šihada 'Ubayd), из Сирије, заједно су са браћом Тејмур били претече покрета названог „Национална књижевнос““ (Hafez, 1993: 181-189, d' Aflito, 2012: 220).

Бругман, у свом делу An Introduction to the History of Modern Arabic Literature in Egypt, назива Махмуда Тејмура „источњачки 
Мопасан“, а Махмуда Тахира Лашина „египатски Чехов“. Многи стручњаци, међу којима је и Сабри Хафиз (Șabrī Hāfiz), називају Лашина пиониром модерне арапске приповетке, јер је, према њиховом мишљењу, он био први писац овог жанра који је достигао веома висок књижевни домет, нарочито у техничком склопу наративног заплета (Hafez, 1993: 219), при чему се у његовом приповедачком стилу преплићу реализам и романтизам. Он представља једну од најистакнутијих личности авангардне књижевне групе, која носи назив Група модерне школе (ар. Ğaмā'at al-madrasa al-ḥadīta). Његове прве приповетке, које су му донеле велики успех, објављене су у часопису $a l$ $F a \breve{g r}$ - „Зора“, који је био гласник књижевног покрета под именом Модерна школа (ap. al-Madrasa al-hadțta). Ова школа је одиграла важну улогу у развоју приповетке, а можда и модерног романа, крчећи пут покрету соцреализма педесетих година (Brugman, 1984: 251).

После педестих и првог оружаног сукоба с новонасталом израелском државом наступа период националног, политичког и отрежњења сваке врсте што је потпомогло рађању не само арапске модерне, пре свега појавом слободног стиха (ap. al-ši'r al-ḥur), већ је изазвао и изузетно живо интересовање за смелост речи.

Но, с развојем политичких прилика, нарочито после шездесетих, настала је тенденција да се све чешће говори о регионалним арапским књижевностима, а не о једној обједињеној арапској књижевности.Наиме, у историјама књижевности арабиста, на пример код Ј. Бјелавског, савремена књижевност се обрађује у оквирима појединих арапских независних држава, на пример, египатска књижевност, ирачка, сиријска, либанска, саудијска итд. (Bielawski, 1968: 536-537).

Седамдесте ће дати пажње вредан покушај да се афирмише проза, нарочито она краће форме, за коју постоји велико занимање међу младима, док ће осамдесете донети велико занимање за роман. Проза постаје најприкладнији начин да се изразе све тежње и море, социјалне и политичке, кроз које пролази арапски свет (Božović, 1986: 11).

\section{3. Генеза палестинске кратке приче у савременој арапској књижевности}

Немири који су на тлу Палестине почели још од првог досељавања Јевреја из света 1917. године, нису били погодни за књижевну 
делатност. Али како је расла политичка и национална свест међу Палестинцима, тако су услови били све бољи за појаву књижевног живота. То је „књижевност отпора“.

Изабела Камера д’Афлито, у својој књизи Савремена арайска књижевности, наводи неколико фаза развоја кратке приче у савременој арапској књижевности. Према ауторки, прва фаза обухвата период од 1870. до Првог светског рата и названа је преводилачком фазом (ap. Maralat al-tarğama). Током ове фазе су се часописи залагали за објављивање приповедака, углавном преведених. Друга или експериментална фаза (ap. Maralat al-muhawala), траје од Првог светског рата до 1925. Трећа фаза, у којој присуствујемо афирмацији модерне арапске приповетке, траје од 1925. до педесетих година двадесетог века (d'Aflito, 2012: 216).

Кључна година историјске, а тиме и књижевне периодизације, јесте 1948. година. То је година оснивања државе Израел. Арапи овај период називају кайасйрофа (al-nakba), и под овим називом подразумевају крај једне и почетак друге епохе. Од тог тренутка ће и друга историјска раздобља бити означена новим речима, као што су поновни пад (ap. alnaksa), пораз (ар. al-hazìma), катастрофа (ap. al-kārița), 1967. године тј. Шестодневни рат, Јом кипурски или Октобарски рат 1973. године.

Абдерахман Јаги ('Abd al-Raḥmān Yāàī) дели историју палестинске књижевности на четири периода. Први период је трајао од средине деветнаестог века до 1908. године, и био је уско везан за традицију. Други је трајао од 1908. до 1920. године, и представља период буђења арапског националног духа. Трећи период, од 1920. до 1940. године, јесте период у ком је палестинско питање постало доминантни мотив у животима арапског живља у Палестини и подстакао палестинску креативност. Књижевност овог периода је била у знаку националне борбе, која је постала кључна тема аутора целокупног арапског поднебља. Четврти период је обележен ишчекивањем краја Другог светског рата, горког рата, чији је резултат била катастрофа (ap. al-Nakba) која је уследила 1948. године (Yāg̀̄̄, 1968: 167).

C друге стране, Насерудин Асад (Nāșir al-Dīn al-Asad) наводи другачију поделу. Он истиче три периода историје палестинске књи-

3 Односи се на етничко чишћење Палестинаца и масовни егзодус близу 850.000 Арапа из Палестине. 
жевности (Yāg̀ī, 1968: 167). Први период који претходи препороду или арапском буђењу, је период транзиције. У том првом периоду који се протеже кроз већи део деветнаестог века, палестинска књижевност, као и сиријска, је била део традиционалне арапске књижевности, која је каскала за египатским и либанским књижевним стваралаштвом, које је увелико пролазило кроз сопствени препород.

У периоду транзиције створили су се услови да и палестинска књижевност достигне ниво, на којем су већ били Египат и Либан. Неки услови су били отварање школа, упознавање Палестинаца са западном културом, отварање великог броја штампарија, оснивање књижевних удружења, итд. Овај други период се поклапа са крајем Првог светског рата, након којег наступа трећи период у којем је палестинска књижевност процветала.

Интифада (ap. al-intifăda) ${ }^{4}$, означава новију фазу сукоба, који је био ограничен, крајем осамдесетих година, тачније 1987. године, на области Западне обале и Газе, који је Израел освојио 1967. године. Све је ово претходило споразуму у Ослу из 1993. године, која се завршила тако што је Палестинцима признат један привид државе.

\section{1. Пионири палестинске кратке приче}

Крајем педесетих година долази до оживљавања књижевног стваралаштва, а нарочито кратке и веома кратке приче, која се захваљујући јасном новинарском стилу показује као најнепосредније средство за бележење пишчевих душевних стања и изражавање брига и немира читаве генерације. У овом периоду, палестински, либански, сиријски и други арапски писци објављују бројне приче у многобројним књижевним и политичким часописима у арапском свету.

Уобичајена је пракса да се палестинска књижевност посматра у складу с хронолошким поделама политичке историје Палестине. У том смислу, под савременом палестинском књижевношћу обично се подразумева књижевност Палестине настала после 1948. године.

Значајни аутори, који су имали улогу у развоју палестинске кратке приче пре Накбе 1948. године, и после ње, су Халил Бајдас (Ḥal̄il Baydas) и Махмуд ел Ирани (Maḥmūd Sayf al-Dīn al-Irānī).

4 Означава палестински устанак против Израела. Први устанак се одвијао између 1987. и 1990. године. 
Бајдасово прозно дело Размишььаъа (ap. Masārih al-adhān), објављено 1924. године (d'Aflito, 2012: 229), је збирка прича коју је писао од 1908. и садржи неколико превода, неколико оригиналних прича и неке адаптиране неарапске народне приче. Ниједна се прича не бави политичким догађајима тог периода (Peled, 1982: 153). Његов роман Наслеgник (ap. al-Wārit), је прича о младој хришћанки Либанки која се преселила у Египат након 1860. и постала жртва Јеврејке плесачице и њене лукаве породице (Peled, 182: 152).

Иранијева књига Прва рунgа (ap. Awal Šawț), из 1937. године. Укључује збирку прича која приказује потребу да се преобрази систем вредности у арапској заједници у Палестини, који је неопходан за делотворну политичку борбу. Аутор у овој збирци, говори и о односу мушкарца и жене, полигамији, незапослености и тешким условима радника и корупцији власти. Све је то описано у овим причама на веома критички начин (Peled, 1982: 158). Иранијева прва збирка је објављена након накбе под називом Ca љуgquмa (ap. Ma' al-Nās), 1955. У њој се бави догађајима пре накбе, док се у другим бави догађајима који су уследили након накбе (Yāg̀̄̄, 1983: 101). Године 1962. објављује збирку Како је ниска иена (ap. Mā aqalal-Taman). Четврта збирка излази 1965, она је уствари његова трећа збирка објављена после накбе и носи назив Kaga jе ноћи крај (ap. Mattā yantahī al-Layl).

Мали број прича из тог периода, је ангажован, и у директној вези са политичким дешавањима. Такве су приче писца Наџати Сид-

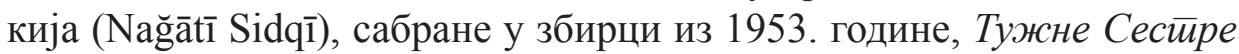
(ap. al-Ahawatal-hazīnāt), описује судбину пет сикомора у улици у Тел Авиву, у периоду када је ова четврт била потпуно арапска (Peled, 1982: 151). Он овде истиче осећања палестинског народа према ционистичком продирању (d'Aflito, 2012: 230). Тема ове збирке су догађаји пре и после накбе.

Друга прича из исте збирке је Дани живойа (ap. 'Ayām min al'umr), где говори о лукавству једне Јеврејке из Немачке, која је преварила младог Арапина, који јој је дозволио да живи у његовој кући (Peled, 1982: 151-152). Прича говори о лукавствима којима се служе ционисти како би присвојили имовину Палестинаца (d'Aflito, 2012: 230). Прича Sham 'ūn Būzaglū описује ортодоксног Јеврејина (Hasīd) како проси на улици, упркос чињеници да је веома богат (Peled, 1982 : 152). 
Кратка прича Назарећанке Наџве Фарах (Nağwā Qa'war Faraḥ),

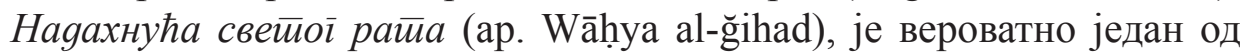
првих покушаја да се рефлектује национална борба у прозном стваралаштву. Прича се бави односом између једног волонтера, који је из Ирака дошао у Палестину ради борбе, и медицинске сестре Палестинке почетком рата 1948. године (Peled, 1982:154). Рођена је у Назарету 1923. Она је почела да пише у периоду мало пре накбе, али је наставила да ствара и после ње. Објављивала је приче у новинама и књижевним часописима од 1950. па све до 1963. године, када је објавила збирку Коме је йролеће (ap. Liman al-Rabī'), која садржи четрнаест прича (Yā̀ì̄, 1983: 100). Превела је збирку под насловом Приче (ap. Qișaș al-aḥdat), објављена 1960. године (Yāg̀ī, 1966: 99).Године 1956. Објављује Освейљене сйазе (ap. Durūb wa mașabīh). Исте године објављује Пролазник (ap. 'Ābirū al-sabīl). Године 1957. оснива заједно са својим супругом часопис $a l-R a$ ’id - „Пионир“. 1965. је објавила неколико чланака о политичким, социјалним и литерарним питањима у штампи. Живела је у Хаифи до средине шездесетих година, а потом се преселила у Канаду. Њене кратке приче, поред наве-

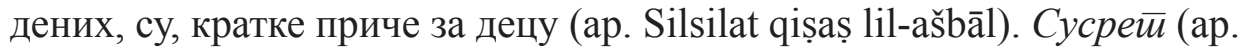
al-Liqa') из 1972. године, и Врайчев устианак (ap. Intifadat al-'assafïr) из 1991. Протагонисти њених прича су, углавном, „обични“ Палестинци, избеглице протеране из својих домова и домовине. Док су многе протагонисткиње у њеним причама снажне и јаке жене, које поред тога што се суочавају са политичком репресијом, суочене су и са дискриминацијом друштва.

Џабра Ибрахим Џабра (Ğabrā Ibrāhīm Ğabrā), рођен 1920. године. У његовим делима је присутна Палестина, од које се растао 1948. године, али с којом ће заувек осећати нераскидиву повезаност иако је провео читав живот у Ираку (d'Aflito, 2012: 287). Nакон накбе објављује 1956. године своју збирку Зној и gруіе йриче (ap. 'īrq wa qișaș uhra), која садржи осам кратких прича и једну причу у три одељка. Објавио је једну збирку кратких прича, а потом позивао писце да се пребаце од писања кратких прича на писање романа (Yāḡì, 1983: 105).

Изузетна ауторка кратких прича је Самира Азам (Samīra 'Azzām). Рођена 1927. године у Аки (Акри), неколико прича објавила у часопису Filaṣtin - „Палестина“, под псеудонимом Fatāt al-Sāhel - „Девојка са обале“. Живела је у Багдаду, Бејруту, на Кипру и у Ира- 
ку где је радила у образовању. У Бејруту је писала и преводила, а 1952. године је водила емисију „Женски угао“ (ap. Rukn al-Mar’a) на радију. Радила је и у америчкој организацији Франклин, за превод и издавање, где је превела неколико дела аутора из Америчке књижевности, попут Перл Бак (Pearl S. Buck), Вурдсворт (Wordsworth), Pej Вест (Ray West) и других. У својој првој збирци под називом Мале стивари (ap. 'Ašya' Șagīira), из 1954. године, у којој ауторка описује живот. Године 1956. излази збирка под насловом Велика сенка (ap. al-Dil al-Kabīr), која садржи дванаест прича о друштвеним проблемима и животу (Yāg̀̄ì 1983: 99). Четврта њена збирка из 1963. године је Човек и caū (ap. al-Sā'a wa al-Insān), jе прича о смрти. Друїe йриче (ap. Qișaș 'uhra) излази 1960. године, која садржи седамнаест прича (Yāg̀ī, 1983: 99). Постхумно је објављена њена пета збирка Празник не улази кроз зайаgни йрозор (ap. al-‘'̄d la ya’tī min al-Nāfida al-ġarbīa) 1971. Писала је о различитим темама али је о проблемима жена на Истоку писала највише. Од шездесетдевет прича које је написала, жена је главни јунак у четрдесет. Дала нам је комплетан опис живота источњачке жене и проблема са којима је суочена. У збирци Шесй ирича (ap. Sit qișaș) говори о палестинском питању, о недаћама Палестинаца у изгнанству после накбе.

Гасан Канафани (Ġassān Kanāfānī), рођен 1936. године. Чувени је палестински романописац. Посветио се политичкој борби, и запоставио је свој велики књижевни таленат (d'Aflito, 2012: 286). Поред романа, од којих је најпознатији Љуgи на суниу (ap. Rīğāl fî'l-Šams), бавио се и кратком причом. У својој првој збирци Из земље йжжних нарании (ap. Arḍ al-Burtuqāl al-Hazīn), која је објављена у Бејруту 1963.године, кроз монолог, је осликао недаће и невоље које су снашле Палестинске избеглице. Године 1965. објављује збирку Свей који није наш (ap. 'Ālam laysa lana), студију о књижевности отпора на окупираним палестинским територијама (1966-1948). Започео је своју књижевну каријеру као аутор кратке приче потом се, попут Џабре, окренуо писању романа (Yāg̀ī, 1983: 102-103, 109).

Емил Хабиби (Imīl Habībī), рођен 1921. године. Никада није пожелео да напусти своју земљу, у којој је као комунистички посланик у Кнесету и новинар, водио сопствену борбу за одбрану арапских грађана у Израелу (d'Aflito, 2012: 289). Позната његова кратка при- 
ча је Минделбаум кайија (ap. Bawābat Mindelbāum), објављена 1945. Касније је објавио збирку прича Шесииина оg шесй gана и gруіе ириче (ap. Sudāsīyāt al-āyām al-sitta wa qișaṣ uḥra), где је на провокативан начин тврдио да је захваљујући том кобном догађају омогућен сусрет двојице браће, то јест Палестинаца из „Окупираних територија“ са онима настањеним у Палестини, која је сада већ постала Израел (d'Aflito, 2012: 288).

Једна од најзначајнијих представница књижевности „Окупираних територија““ (d’Aflito, 2012: 290), је Сахар Халифа (Sahar Ḥalīfa). Рођена је 1941.године. Значајни је писац романа, кратких прича и драме. Поред политике, ангажована је и на друштвеном плану. Своје прве романе посвећује женама и њиховом положају у друштву. Године 1974. издаје свој први роман Нисмо више ваше робиње, на основу којег је направљена серија. Године 1980. објављује роман Сунцฺо$к р е \bar{u}$. Позната је по роману Дивље йрње, из 1984. године, који се бави конфликтом између Палестинаца и израелске војске. Роман из 1986. Мемоари нереалне жене, где ауторка на негативан начин описује уговорени брак. Сматра се аутобиографским, јер је произашао из ауторкиног, личног и горког искуства с уговореним браком.

Она у својим делима говори о проблемима попут колаборационизма, отпора, побуне (d'Aflito, 2012: 291). Delo Наслеђе, из 1997. се бави споразумом из Осла 1993. године. Њена дела су преведена на немачки, енглески, хебрејски, руски и шведски језик. Професор је књижевности и предавала је на универзитету у Ајови и на Bir Zeit универзитету у Рамали. Основала је први „женски центар“ (енгл. The Women's Affair Center), у Наблусу, Гази и Аману, у чијем је средишту, економско и политичко оснаживање жена. Године 2010. објавила ро-

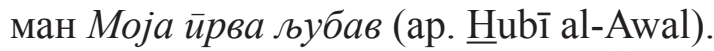

Махмуд Шукајр (Маһ̆mūd Šuqayr), рођен 1941. у Јерусалиму. Књижевним стваралаштвом се бави од шездесетих година XX века. Пионир је веома кратке приче. Поред веома кратких прича, пише приповетке, и приче намењене деци и омладини. Своју прву збирку прича објављује 1975. године, под називом Туђи хлеб (ap. Hubz al-aharīn). Након што је протеран из Палестине у Либан, радио је као уредник часописа „Filaștīn al-Tawra“, потом се преселио у Јордан, где се бавио образовањем, новинарством и писањем. Вратио се у Палестину 1993. 
године, као део прве групе протераних, којима је, због споразума из Осла, дозвољен повратак. Радио је као уредник, а потом постао главни и одговорни уредник недељника , al-Ṭalī‘ā al-Muqadasīā‘. Тренутно живи и ради у Рамали. Његове збирке прича су, Туђи хлеб (Hubz al-aḥarīn), из 1975. Палестиински дечак (ap. al-Walad al-Falașțīnī), из 1977. године. Рийуали нваљале жене (ap. Tūqūs al-Mar'a al-Šaqīya), из 1986. Руже за крв Пророка (ap. Ward li-Dimā' al-Anbīyā'), 1991. Пролаз оймичара (ap. Murūr Ḥātef), 2002. Приче написане у периоду интифаде, а нису се њом бавиле, су Шакирина слика (Șūrat Šakīrā),

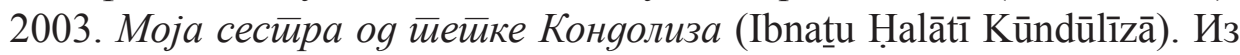
2004. Наров земље (Ahl al-Balad). Причу Слабе могућносиии (Ihtimalāt Țafifa), објављује почетком 2006. године (Sulaīmān, 2011: 4-25).

Лиана Бадр (Līāna Badr), рођена је 1950. у Јерусалиму. Многи је сматрају најплоднијим писцем арапског света. Поред романа, бавила се и кратком причом. Написала је збирку песама и књиге за децу које су преведене на многе светске језике, као што су шпански, немачки, норвешки, пољски, корејски и многе друге. Била је уредник часописа

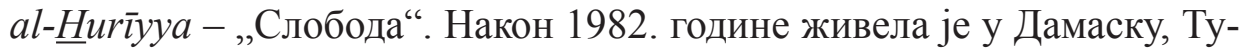
нису, и Аману, да би се у Палестину вратила 1994. године. Била је на челу одсека за филм и аудиовизуалне ефекте, при палестинском министарству културе. Била је уредник часописа Dafater Taqāfìya - „Културне свеске“. Њена дела, преведена на енглески језик су, Compass of the Sunflower, роман из 1989. Hell of Gold: stories, из 1991. A Balcony over the Fakihani, из 1993. The Stars of Jericho, из 1993.Lillies light, из 1998. The Eye of the Mirror, из 2008. „, March of the Dinosaurs “.Freedom: Stories celebrating the Universal Declaration of Human Rights, из 2011.

Бавила се и кратким филмом. Њена филмографија је, Fadwa:A Tale of a Palestinian Poetess (1999), Zeitounat (2000), The Green Bird, 2002.Siege (A Writer's Diary), 2003. године. The Gates are Open. Sometimes!(2006). A match on Thursday Afternoon, 2006. године .Al Quds -My City 2010. У својим остварењима бавила се животом под окупацијом, отпором и покоравањем, инииифаgом, изгнанством и побунама. У роману Око оіллеgала, се бави геноцидом у кампу Тал ел Затар (ap. Tal al-Za'tar), избегличком кампу у Бејруту и описује једну од најгорих опсада у историји либанских грађанских ратова, (Mehta, 2007: 28-41). 
У новију генерацију писаца спада и Ранда Џарар (Randa Ğarār), Рођена је 1978. године, у Чикагу. Пише романе, кратке приче и преводи. Одрастала је у Кувајту и Египту, потом се са тринаест година сели у Њујорк. Први роман Майа gомовине (2008), је прича о младој арапкињи-американки Нидали, која на хумористчан начин описује своје детињство. Објављен је у Сједињеним Државама, Италији, Немачкој, Тајвану, Кини и Израелу. Кратка прича Замишьам себе у Палесиинни описује покушај ауторке да посети Палестину (Jarrar, 04.03.2014. у 19.00 ч.)

Добитница је бројних награда за роман и кратку причу, попут, Million Writers Award, 2004. за најбољу кратку причу објављену на интернету, коју додељује „storySouth“. Hopwood Award, за најбољи роман 2007. Chamberlain Prize, 2008. Arab American Book Award, 2009. Учествовала је у пројекту Beirut 39 (Best 39 writers of Arab origin under $40)$ и за исти награђена, 2010. године (PEN, 03.05.2010 у 22.30 ч.)

\section{3. Закључак}

Живот арапског света парадигмично показује да се политика и књижевност чврсто прожимају. Политичка ситуација се неизбежно одражава на арапске, а посебно палестинске писце који су искусили многе трауме, изазване прогонствима, животом у туђини, избегличким логорима, а нарочито свим врстама злоупотребе, у своје текстове претачу тескобу и страхове. Тако ће се у њиховим приповеткама и другим прозним делима све упорније говорити о прогонству и отуђености (ap. gurba), оном осећању отуђености, удаљености и усамљености, коју може осетити чак и онај ко остане у својој домовини, попут Емила Хабибија, који каже да отуђеност осећа и он сам, да се, иако је остао у својој домовини, осећа као странац у сопственој кући (d'Aflito, 2012: 367). У Палестини, као што смо видели, има много писаца кратких прича, који се баве најразличитијим темама. Писали су о отуђености, отпору, повратку, друштвеним и политичким неприликама којим су изложени, а неки су кроз хумор описивали бол и патњу кроз коју су пролазили. У делима која су настала у периоду накбе, примећује се пишчева преокупација изгнанством, простором и тадашњим догађајима, било друштвеним или политичким. Период Шестодневног рата, симболише прекретницу, кроз коју се фор- 
мира јаснија свест о самоопредељењу и идентитету. Пажњу аутора, кроз педесете и шездесете, окупира питање и проблем егзистенције. Кључна питања су, такође, мотив граница и симбол жене. Код свих ових аутора, више него код других писаца из разних араских земаља, постоји једна особеност, нит водиља кроз палестинску земљу, која ће бити приметна и у наредним генерацијама.

\section{Литература}

Bielawski, Jozef (1968). Historia Literatury Arabskiej. Wroclav: Zaklad Narodowy Imienia Ossolinskich - Wydawnictwo.

Brugman, J. (1984). An Introduction to the History of Modern Arabic Literature in Egypt. Leiden:Brill.

Božović, Rade (1986). Antologija kratke arapske priče. Kruševac: Bagdala.

D’Afflito, C. Isabella (2012). Savremena arapska književnost. Beograd; Zavod za udžbenike.

Gabrijeli, F. (1985). Arapska Književnost. Sarajevo: Svijetlost.

Haywood, A. John (1971). Modern Arabic Literature 1800-1970. London: Lund Humphries.

Hafez, Sabry (1993). The Genesis of Arabic Narrative Discourse. London: Saqi Books.

Jarrar, Randa (2014, March 04). About Randa Jarrar [Video file]. Доступно преко: http://www.randajarrar.com/about/ [22.03.2014.]

Mehta, J. Brinda (2007). Rituals of memory: in contemporary Arab women's writing. New York: Syracuse University Press.

Pellat, Charles (1970). Langue et Littérature Arabes. Paris: Libraire Armand Colin.

Peled, M. (1982). Annals of Doom. Palestinian Literature 1917-1948. U Arabica, XXIX, 143-83.

PENAmerica.(2010, May 03).Incognito: writersand their Aliases [Videofile]. Доступно преко: http://www.youtube.com/watch?v=qTb1pF21DPk [ 11.03.2014.]

Sulaīmān, D. Amān̄̄ (2011). Hawīyat al-Qișa al-Qașīrā 'nd Mahmūd Šuqaīr. al-Urdun: Ğmi`at al-Batra. 
Tanasković, D. i Mitrović, A. (2011). Gramatika arapskog jezika. Beograd: Zavod za udžbenike.

Yà̀ì̄, 'abd al-Rahmān (1983). F̄̄ al-adab al-filastīnī al-hadītq qabl alnakba wa ba'dahā. Kūwaīt: Šarikat kaḍima lil-našr wa al-tarğama wa al-tawzī'.

Yāg̀ī, Hāšim (1966). Al-Qiș̣a al-qașīra fì Filasțīn wa al-Urdun 18501965. Al-Qahira: Ma'had al-buhụt wa al-dirāsāt al-'arabiya.

Маи Г. Ел Геридли

\section{Summary \\ PALESTINIAN SHORT STORY IN THE MODERN ARABIC LITERATURE}

This text deals with the Palestinian short story in contemporary Arabic literature. Palestinian literature has a special place in history of Arabic literature, because it is deeply linked to the political events, and to literature itself. The Palestinian short story, as the Arabic, deals with issues of national liberation and struggle against imperialism and colonialism. This literature has sought to identify and highlight significant moments in Arab history. First and foremost the focus is, mainly on, the painful and traumatic problem of the Palestinian people since 1948. who have been thrown out of their homes and homeland. The first part of the paper deals with the creation and development of the modern short story in the Arab world, in general, and the Palestinian, in particular. While in the second part we present the most prominent Palestinian writers of modern short story and their work. 